ISSN 0258-7122

Bangladesh J. Agril. Res. 40(2): 291-304, June 2015

\title{
TECHNICAL AND ECONOMIC PERFORMANCE OF COMBINED HARVESTER IN FARMERS' FIELD
}

\author{
M. A. HossAIN ${ }^{1}$, M. A. HoQUE ${ }^{2}$, M. A. WOHAB ${ }^{3}$ \\ M. A. M. MIAH ${ }^{4}$ AND M. S. HASSAN ${ }^{5}$
}

\begin{abstract}
Labour scarcity, harvesting loss, timely harvesting and harvesting cost are crucial in rice and wheat harvesting in Bangladesh. Combine harvester is a newly introduced harvesting machine in Bangladesh. This study was undertaken to evaluate the technical and economic performance of combine harvester available in farmers' field and farmer's perception regarding the use of combine. Field tests of two new (CLASS andDaedong) and two refresh (Kukje and Anower) combine harvesters were conducted for harvesting rice and wheat in the farners' field of Jessore, Pabna,Dinajpurand Thakurgaon districts during 2011-12. Primary data were collected from 30 adopter and 30 non-adopter farmers from each district of Bogra, Rangpur, Dinajpur and Thakurgaon through direct interviewingduring 2012-13. Information was also collected from different combine harvester traders available in Bangladesh. Average time, cost and grain saving by combine harvester over manual methods were 97.50, 35.00 and $2.75 \%$, respectively. Benefit cost ratio of CLASS, Daedong, Kukje and Anower combine harvesters were found to be 2.68, 2.11, 2.29 and 2.70, respectively. The payback periods of refresh combine harvesters were lower than the new combine harvester. There were some mechanical problems observed in refresh combine harvesters during field operations. New harvester was observed almost trouble free and popular to the famers. Scarcity of spare parts and mechanic service were the main problems for repair and maintenance of the combine harvesters in farm level. Considering the technical performance of combine harvester and demand of the farmers, new combine harvester may be introduced in commercial basis in Bangladesh.
\end{abstract}

Keywords: Benefit cost ratio, field capacity, harvesting efficiency,harvesting loss, payback period, rice, wheat.

\section{Introduction}

Rice and wheat are the most important and staple food of Bangladesh. At present, rice and wheat production is about 30.52 million ton over an area of 11.73 million hectares. More than $80 \%$ of the cultivable land is under rice and wheat cultivation (Talukder, 2013). Almost allamount of these crops are harvested manually by sickle which is laborious, time consuming and costly. Harvesting and threshing are the most important operations in the entire range of field

${ }^{1,2,3 \& 5}$ Farm Machinery and Postharvest Process Engineering Division, Bangladesh Agricultural Research Institute (BARI), Gazipur-1701, ${ }^{4}$ Agricultural Economics Division, BARI, Gazipur-1701, Bangladesh. 
operations, which are laborious involving human drudgery and requires about 150-200 man-h/ha for harvesting of paddy alone (Salassi and Deliberto, 2010; Veerangoudaet al., 2010).

Timely harvesting is utmost important, as delayed harvesting leads to a considerable loss of grain and straw owing to over maturity resulting in loss of grains by shattering and also delays in seed bed preparation and sowing operations for the next crop. The paucity of labour in the peak harvesting season is forcing the farmers delay harvesting causing high postharvest losses and sometimes loss of the crop by natural calamities. Due to increase of cropping intensity and production of different crops, the demand of agricultural labour has increased significantly. The labour scarcity is very high during the harvesting period of wheat and boro rice (Ahmmed, 2014). On the other hand, many agricultural labours have been migrating to other off-farm activities like garments and other industries, transportation, small business, road and building construction, etc. Due to delay harvesting, a large quantity of grain is lost each year in the country. Bala et al.(2010) reported that post harvest losses of rice at farm level were $9.49 \%, 10.51 \%$ and $10.59 \%$ for aman, boro and aus season respectively.

To reduce the harvesting loss and cost, timely harvesting of paddy and wheat is very important. A well designed, combine harvester can play an important role in harvesting of paddy and wheat in time, efficiently and in less cost. There are different types of combine harvestersintroduced by different traders and DAE (Department of Agriculture Extension) and using in the farmers' fields. Therefore, this study was undertaken to evaluate the technical and economic performance of combine harvestersavailable in farmers' fieldsand to find out the suitability of the machines in the socio-economic conditions of the farmers of Bangladesh.Main features of different types of combine harvesters imported/made by different companies are given in Table 1 . The Metal Private Limited, ACI Motors and Corona Tractors Limited started to import combine in 2008, 2010 and 2011, respectively. The Metal Private Limited imported new CLAAS combine harvester from India. ACI Motors imported both new and refresh Daedong combine harvester from South Korea. The Corona Tractors Limited imported both new and refreshDaedong and Kukje combine harvesters from South Korea. CLAAS had both wheel type and crawler type combine harvester whereas Daedong and Kukje had crawler type combine harvester. Wheel type combine harvester is suitable in dry land harvesting especially for wheat harvesting. On the other hand, crawler type combine harvester can be used in wet land harvesting. It can also be used in dry land but wheel type was difficult in use in wet land harvesting. The Metal Private Limited and ACI Motors sold 69\% and 90\%, respectively of their imported combine harvesters but 
Corona Tractors Limited and AnowerHossain could not sell any combine harvesters up to the data collection time. Engine power, weight, cutting width, grain tank capacity and field capacity of CLAAS combine were higher than other combine harvesters. Also the price of CLAAS combine harvester was much higher than Daedong and Kukje combines. Price of new Daedong combine was Taka 25,000,00, whereas the price of refresh combine ( 800 hours used) of same model was Taka 9,40,000. The price of AnowerHossain fabricated combine harvester was the lowest, Taka 7,50,000. Anower's combine harvester worked well in both dry land and wetland conditions but it was not extensively used and not commercialized.

\section{Materials and Method}

In 2010, refresh combine harvesters were imported from South Korea by ACI Motors Limited and was sold to the project "Enhancement of crop production through farm mechanization" implemented by Department of Agriculture Extension (DAE). The Metal Private Limited, ACI Motors and Corona Tractors Limited are the main importers of combine harvesters in Bangladesh. Mr. AnowerHossain of Fulbari, Dinajpur fabricated two combine harvesters locally (Fulbari Engineering Workshop, Fulbari, Dinajpur) in 2012 withmost of the spare parts of other rejected imported combine harvesters (Prothomalo, 2013). He used a $35 \mathrm{hp}$ single cylinder old diesel engine as power source. He also made some parts with locally available materials such as reel, conveyer belt, thresher, etc.

Refresh combine harvesters (Daedong (DSM-55) and Kukje (KC-515)) were tested in the farmers field for harvesting rice and wheat in Dinajpur and Jessore and new combine harvesters, CLASS (Crop Tiger 30) and Daedong (DSC48) were tested inThakurgaon and Pabna during 2010-11. Most of the owners used the combine harvesters commercially rented for harvesting wheat, transplanted aman rice and boro rice. Data were collected directly from farmers' field during operation. Harvesting suitability, capacity, fuel consumption, problems during operation and farmers perceptions were recorded during operation in the farmers' fields. Data were also collected from marketing companies (traders) of combine harvester such as ACI Motors, The Metal Private Limited and Corona Tractors Limited through structured questionnaire during 2011-12. During 2012-13 field survey were conductedin the farmersfields in Sherpurupazila of Bogra,Fulbariupazil of Dinajpur, Baliadangaupazila of, Thakurgaon and Peergonjupazila ofRangpur districts. The study locations were selected purposely where combine harvesters were used for harvesting rice and wheat. The respondents were, farmers and they were categorized as adaptor and non-adaptor groups. Thirty adaptor farmers and 30 non-adaptor farmers were interviewed through pre-tested questionnaire. 
Depreciation of combine harvester was calculated by straight line method. Gross return was obtained from income generated by each of the combine harvester from custom hire basis during the harvesting of aman rice, boro rice and wheat in a year. Seasonal use, harvesting rate, fuel consumption, operator's wage etc. data were collected from the selected locations by direct interviewing of the combine harvester owners and adopter farmers.Data were analyzed by standard statistical methods and presented in tabular form.

\section{Results and Discussion}

\section{Field performance evaluation}

The field performance of different types of combine harvesters are given in Table 2. The threshing mechanism of CLASS combine harvester was axial flow mode but other combine harvesters had head feed mode. The highest theoretical and effective field capacities were found for CLASS combine harvester due to its highest width of cut and forward speed. The filed capacities of Daedong and Kukje combine harvesters were almost similar but the lowest field capacity was found for AnowerHossain's combine harvester. The reason might be that AnowerHossain'scombine harvester was operated at the lowest forward speed,because this combine harvester was operated by a single cylinder engine and more vibration at higher speed. The harvesting efficiencies of all combine harvesters were found above $95 \%$ and those quite good for harvesting rice. Grain loss of rice was higher that of wheat because normally shattering loss of rice is higher than wheat. Kabir and Zaman found $4.62 \%$ field loss during harvesting of boro rice by CLASS combine harvester. Pawar et al. (2008) reported that total field loss of combine harvester for wheat in India was $4.20 \%$. So, the data presented in this study agreed well with this result.During harvesting of crops by combine harvester, harvesting, threshing and winnowing are done at a time. So, the colour and appearance of grains remains same as for standing crops. But for manual harvesting, threshing and winnowing methods, these operations are done separately and different times. Therefore, the colour of grains becomes pale. In machine harvesting method, the straw broken and fractured in axial flow mode and straw remained long but fractured in head feed mode of threshing. But in manual harvesting and threshing method straw remains well condition. This was a disadvantage of combine harvesters reported by the farmers.

Uses of different types of combine harvesters during 2011-12 are given in Table 3.Total operating days per year for harvesting rice and wheat during 2011-12 by 3 model (CLAAS (Crop Tiger 30), Kukje (KC-515)/ Daedong (DSM55) and Anower model) were 40 days but that ofDaedong (DSC48) model was25 days. The reason was that Daedong (DSC48) had some mechanical problems during the boro rice harvesting season.In this period The Metal (Pvt.) Limited, ACI Motors, Corona Tractors Limited and AnowerHossain used 25, 4, 25 and 2 


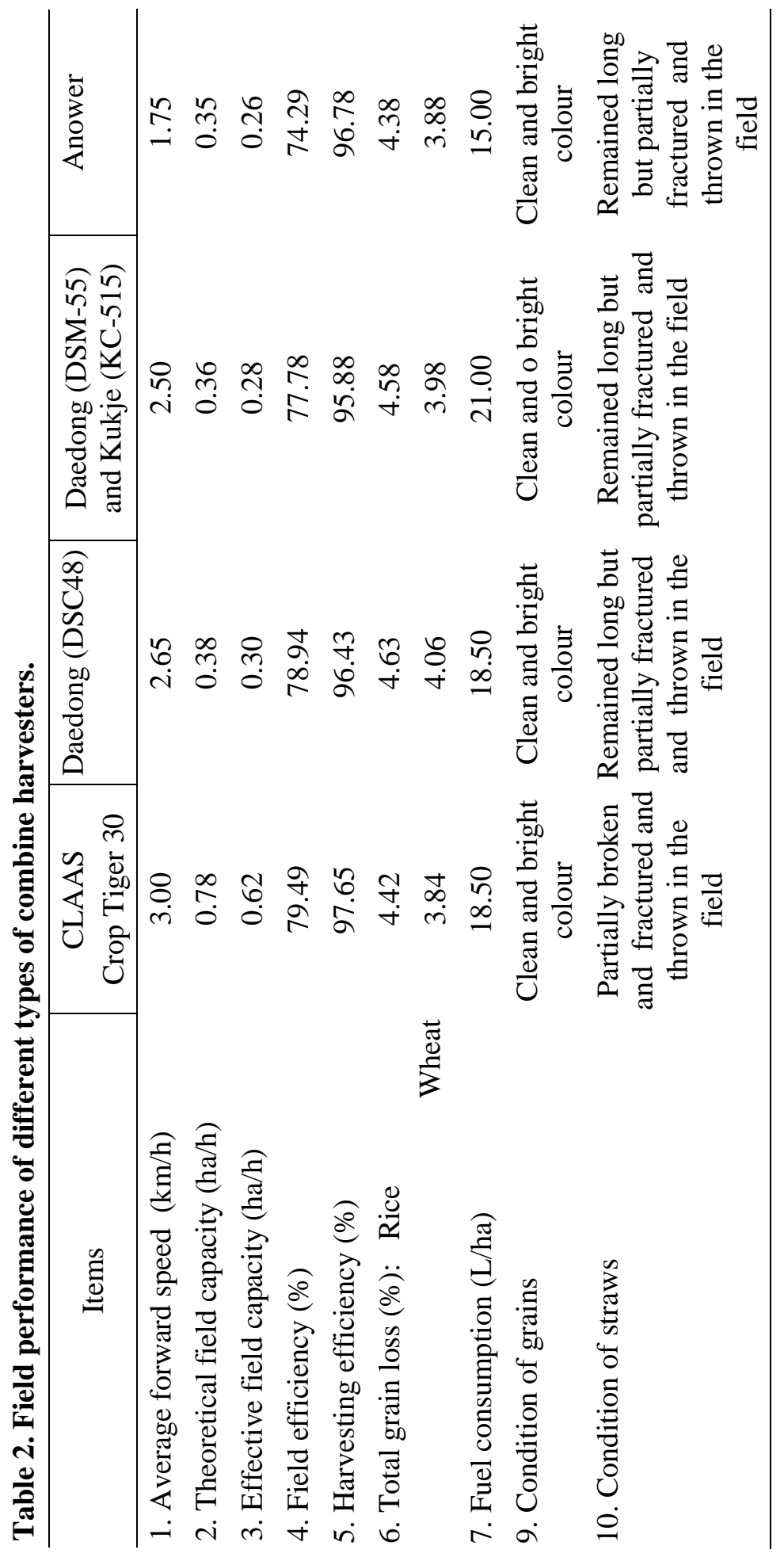


numbers of combine harvesters, respectively for harvesting of rice and wheat. With these combine harvesters, The Metal Private Limited, ACI Motors and Corona Tractors Limited and AnowerHossainharvested 203, 57 and 410 and 15 ha of crops, respectively. AnowerHossain could not harvest any wheat during 2011-12 period because his harvesters were not completed in fabrication before wheat harvesting season. Average harvested by one harvester per year was the highest by Kukje (KC-515)/ Daedong (DSM55) combine harvester followed by Daedong (DSC48), and CLAAS (Crop Tiger 30) models and the lowest was recorded for Anower model.

Table 3.Uses of different types of combine harvesters in the farmers' fields during 2011-12.

\begin{tabular}{l|c|c|c|c}
\hline \multicolumn{1}{c|}{ Items } & $\begin{array}{c}\text { The Metal } \\
\text { (Pvt.) Ltd. }\end{array}$ & $\begin{array}{c}\text { ACI } \\
\text { Motors }\end{array}$ & $\begin{array}{c}\text { Corona Tractors } \\
\text { Ltd. }\end{array}$ & AnowerHossain \\
\hline $\begin{array}{c}\text { Model of combine } \\
\text { harvester }\end{array}$ & $\begin{array}{c}\text { CLAAS } \\
\text { (Crop Tiger } \\
\text { 30) }\end{array}$ & $\begin{array}{c}\text { Daedong } \\
\text { (DSC48) }\end{array}$ & $\begin{array}{c}\text { Kukje (KC-515)/ } \\
\text { Daedong } \\
\text { (DSM55) }\end{array}$ & Anower \\
\hline $\begin{array}{l}\text { 1.Operation days per year } \\
\text { 2.Total numbers used }\end{array}$ & 40 & 25 & 40 & 40 \\
$\begin{array}{l}\text { 3.Total area harvested } \\
\text { (ha/yr) }\end{array}$ & 203.00 & 57.00 & 410.00 & 2 \\
$\begin{array}{l}\text { (a) Aman rice } \\
\text { (b) Boro rice }\end{array}$ & 61.00 & 20.00 & 130.00 & - \\
$\begin{array}{l}\text { (c) Wheat } \\
\text { 4. Average area harvested } \\
\text { by each harvesters (ha) }\end{array}$ & 81.00 & 27.00 & 140.00 & 15.00 \\
\hline
\end{tabular}

The Metal Private Limited imported 29 numbers of combine harvesters and sold 20 numbers since 2008. Among 20 combine harvesters, 13 were sold to government organizations and seven were sold to farmers (Table 4). The ACI Motors imported 40 numbers of combine harvesters and sold 36 numbers since 2010. Among them, only one combine harvester was sold to farmer and another 35 were sold to government organizations. ACI Motors sold 25 refresh combine to DAE and other sold combine harvesters were new. The Corona Tractors Limited could not sell any combine harvester although they imported 45 in 2011. They were mainly using these combine harvesters for demonstration and custom hire service. Mr. AnowerHossain of Dinajpur fabricated two combine harvesters locally in 2012 and harvested boro rice on custom hire basis during of 2013 in Dinajpur area. 
Table 4. Numbers of combine harvesters sold/demonstrated by different companies.

\begin{tabular}{l|c|c|c|c|c}
\hline \multicolumn{1}{c|}{ The Metal (Pvt.) Ltd. } & \multicolumn{2}{c|}{ ACI Motors } & \multicolumn{2}{c}{ Corona Tractors Ltd. } \\
\hline \multicolumn{1}{c}{ District/ } & Numbanization & $\begin{array}{c}\text { District/ } \\
\text { Organization }\end{array}$ & Number & $\begin{array}{c}\text { District/ } \\
\text { Organization }\end{array}$ & Number \\
\hline BADC & 12 & DAE (Refresh) & 25 & Faridpur & 1 \\
BAU & 1 & BARI (New) & 3 & Natore & 1 \\
Dinajpur (Farmer) & 1 & BADC (New) & 6 & Bogra & 1 \\
Comilla (Farmer) & 1 & BRRI (New) & 1 & Netrokona & 1 \\
$\begin{array}{l}\text { BrahmonBaria } \\
\text { (Farmer) }\end{array}$ & 1 & Dinajpur (New) & 1 & & \\
Dhaka (Farmer) & 1 & & & & \\
Bogra (Farmer) & 1 & & & & \\
Joypurhat (Farmer) & 1 & & & \\
Mymensingh & 1 & & & \\
(Farmer) & & & & \\
\hline Total & & & & \\
${ }^{*}$ Demonstrated only. & &
\end{tabular}

\section{Field survey result}

Socio-economic conditions of combine harvester adaptor and non-adopter farmers in the selected study areas are given in Table 5 and Table 6 , respectively. Thirty adaptor farmers and 30 non-adaptor farmers were interviewed in each study area (district). Average age of an adaptor farmer (40.00 years) was higher than non-adaptor farmers (37.50 years) but their difference was not much higher. Age of adaptor farmers in the study areas ranged from 35 to 45 years. But the age of non-adaptor farmers in the same study areas ranged from 31 to 44 years.

In case of combine harvester adaptor farmers, they were all educated at different levels. But, average $12.57 \%$ of farmers were illiterate in the non-adaptor group. Degree level educated farmers were in the adaptor group. But in non-adaptor group no degree level educated farmers were found in Bogra, Rangpur and Dinajpur districts. Only $6.25 \%$ degree level non-adaptor farmers were in Thakurgaon district. It is evidence from the study that education was an important factor for adopting combine harvester for harvesting rice and wheat. It is observed from the tables that adaptor farmers owned more cultivated land than non-adaptor farmers. Generally rich farmers are more progressive and influential than the poor farmers in the society and the rich farmers come forward to adopt new technology. So, land size was another factor for adopting combine harvester. It is also observed from the table that both adaptor and non-adaptor farmers of Thakurgaon district cultivated wheat along with aman and boro rice. 
Table 5. Socio-economic conditions of combine harvester adaptor farmers in the selected areas.

\begin{tabular}{lccccccc}
\hline \multicolumn{1}{c|}{ Parameters } & Bogra & Rangpur & Dinajpur & Thakurgaon & Average \\
\hline Age of respondents (year) & 35 & 45 & 44 & 37 & 40 \\
Education of Illiterate & 0 & 0 & 0 & 0 & 0 \\
respondents & Primary & 36.36 & 28.57 & 42.86 & 31.25 & 34.76 \\
$(\%)$ & SSC & 36.36 & 31.46 & 29.86 & 43.75 & 35.36 \\
& HSC & 18.18 & 25.47 & 25.28 & 6.25 & 18.80 \\
Cultivated land (ha) & 1.87 & 2.13 & 1.60 & 4.00 & 11.09 \\
Aman (ha) & 1.73 & 1.73 & 1.60 & 2.40 & 1.87 \\
Boro (ha) & 1.73 & 1.73 & 1.60 & 0.80 & 1.46 \\
Wheat (ha) & 0 & 0 & 0 & 2.00 & 0.50 \\
Other crops (ha) & 0.42 & 0.35 & 0.23 & 1.56 & 0.64 \\
\hline
\end{tabular}

Table 6. Socio-economic conditions of combine harvester non-adaptor farmers in the selected areas.

\begin{tabular}{|c|c|c|c|c|c|}
\hline Parameters & Bogra & Rangpur & Dinajpur & Thakurgaon & Average \\
\hline Age of respondents (year) & 31 & 34 & 44 & 41 & 37.50 \\
\hline \multirow{5}{*}{$\begin{array}{l}\text { Education o } \\
\text { respondents } \\
(\%)\end{array}$} & 8.33 & 15.87 & 13.58 & 12.50 & 12.57 \\
\hline & 41.67 & 35.20 & 43.56 & 37.50 & 39.48 \\
\hline & 36.42 & 30.56 & 28.57 & 27.00 & 30.64 \\
\hline & 13.58 & 18.37 & 14.29 & 16.75 & 15.75 \\
\hline & 0 & 0 & 0 & 6.25 & 1.56 \\
\hline Cultivated land (ha) & 1.07 & 0.67 & 1.06 & 1.46 & 1.06 \\
\hline Aman (ha) & 1.06 & 0.53 & 0.93 & 0.93 & 1.07 \\
\hline Boro (ha) & 1.06 & 0.40 & 1.06 & 0.40 & 0.86 \\
\hline Wheat (ha) & 0 & 1.07 & 0 & 0 & 0.73 \\
\hline Other crops (ha) & 0.34 & 0.36 & 0.14 & 0.86 & 0.43 \\
\hline
\end{tabular}

Uses and resource saving by different combine harvesters in the selected study areas during 2012-13 are shown in Table 7. In Bogra and Thakurgaon CLASS combine harvester was used for harvesting boro rice and wheat, respectively. Crawler type and wheel type combine harvesters were used for harvesting rice and wheat, respectively. In Rangpur, crawler type Kukje combine harvester was used for harvesting boro rice. In Dinajpur, Mr. AnowerHossainmade combine harvester was used for harvesting boro rice. Mr. Al Amin of Sherpurupazila, Bogra bought CLASS combine harvester in 2009. He harvested his own crops, 23 ha and used it for other farmers' field as custom hire basis. Corona Tractor Limited and The Metal (Pvt) Limited harvested rice and wheat in Rangpur and 
Thakurgaon, respectively. All the study areas, custom hire basis was used for harvesting of rice and wheat. Harvesting charge varied from location to location. The highest harvesting charge of rice was in Bogra (10,500 Tk./ha) and the lowest was in Rangpur (9,000 Tk./ha). The reason was that in Bogra harvesting was done commercially by a combine harvester owner but in Rangpur, harvesting was done under a demonstration type program by a company. By combine harvester harvesting threshing and winnowing are done at a time but in manual method these operations are done simultaneously. In manual method average harvesting, threshing and winnowing cost per hectare (Tk. 16131) was 35\% higher than average cost of harvesting (Taka 10500) by combine harvester. Pawar et al. (2008) reported the cost of operation for combine harvester was $(817.84 \mathrm{Rs} / \mathrm{ha})$ was less than the combination of self propelled reaper with thresher (1816.79 Rs/ha). Average time saving for harvesting, threshing and winnowing of rice and wheat by combine harvester over manual method was $97.5 \%$. Average $2.75 \%$ of grain loss reduced by harvesting of rice and wheat by combine harvester. Time and grains savings attracted the farmers for using combine harvester.

\section{Economic performance}

Economic performance of different types of combine harvesters in farm level is given in Table 8 . The basic data presented in this table were collected from the combine harvester owner. Economic lives of new and refresh combine harvesters were assumed to be 10 and five years, respectively. During the harvesting season, combine harvester was effectively operated for 10 hours in a day.The highest gross return was obtained from CLASS combine harvesters followed by Daedong and Kukje combine harvesters. The highest net return was found from CLASS combine harvesters (37,20,000 Tk./year) followed by Anower combine harvester. The net return from Daedong and Kukje combine harvesters were similar. The highest benefit cost ratio (BCR) was obtained from Anower combine harvester followed by CLASS, Kukje and Daedong combine harvesters. The reason was that the fixed and variable costs of Anower combine harvester were the lowest due to its lowest price, lowest fuel consumption and low cost of somelocally made spare parts. But the harvesting charge was the same for all types of combine harvesters. BCR of CLASS, Daedong, Kukje and Anower combine harvesters were found to be 2.68, 2.11, 2.29 and 2.70, respectively. Thepayback periods of refresh combine harvesterswere the lower than the new ones due to lower price of refresh combine harvesters. Thoughthe highest BCR and low payback period of Anower model were obtained, it is hardly possible to make it commercially available in large scale due to multivariable spare parts. So, new and refresh combine harvester may be introduced. Because, a good demand of use of combine harvester has been created in the study areas. 


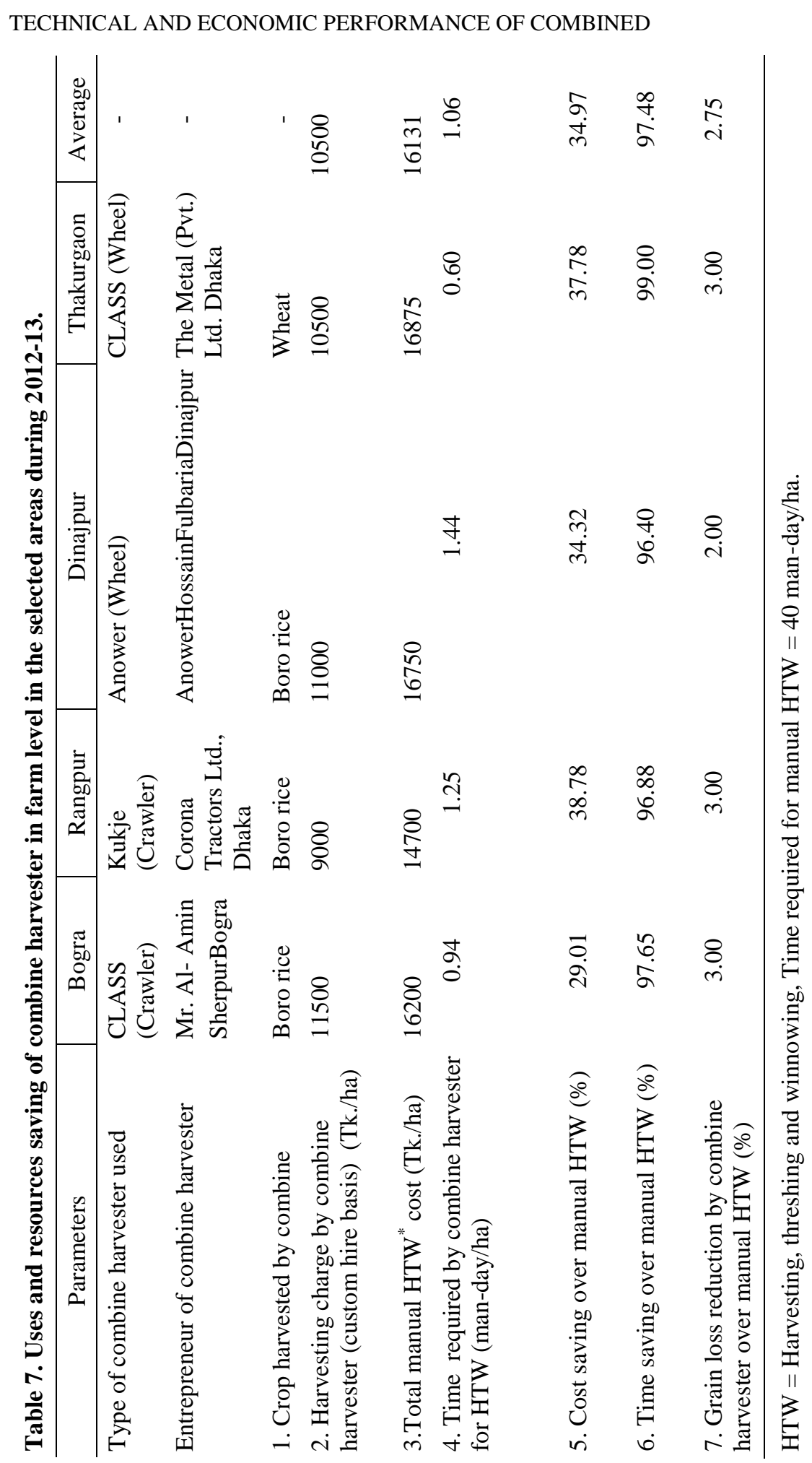


Table 8.Economic performance of different combine harvesters in farm level.

\begin{tabular}{|c|c|c|c|c|}
\hline Cost items & $\begin{array}{l}\text { CLASS (Crop } \\
\text { Tiger 30) } \\
(\text { New) }\end{array}$ & $\begin{array}{l}\text { Daedong } \\
\text { (DSC48) } \\
(\mathrm{New})\end{array}$ & $\begin{array}{c}\text { Kukje (KC- } \\
515) \\
\text { (Refresh) }\end{array}$ & $\begin{array}{l}\text { Anower } \\
\text { (Refresh) }\end{array}$ \\
\hline 1.Price (Tk.) & $42,00,000$ & $25,00,000$ & $9,40,000$ & $7,50,000$ \\
\hline 2. Economic life (year) & 10 & 10 & 5 & 5 \\
\hline 3. Depreciation (Tk./yr) & $3,78,000$ & $2,25,000$ & $1,69,200$ & $1,35,000$ \\
\hline 4. Bank interest (14\%) (Tk./yr) & $3,23,400$ & $1,92,500$ & 72,380 & 57,750 \\
\hline 5. Shelter (Tk./yr) & 10,000 & 10,000 & 10,000 & 10,000 \\
\hline a. Fixed cost $(3+4+5)(T k . / y r)$ & $7,11,400$ & $4,27,500$ & $2,51,580$ & $2,02,750$ \\
\hline $\begin{array}{l}\text { 6. Effective harvesting hour per } \\
\text { day }\end{array}$ & 10 & 10 & 10 & 10 \\
\hline $\begin{array}{l}\text { 7. Average harvesting hour per } \\
\text { year (Aman-15, boro- } 25 \text {, } \\
\text { wheat- } 20 \text { days) }\end{array}$ & 600 & 600 & 600 & 600 \\
\hline $\begin{array}{l}\text { 8. Fuel (diesel) consumption } \\
(\mathrm{L} / \mathrm{h})\end{array}$ & 18.5 & 18.5 & 21.0 & 15.0 \\
\hline 9. Harvested area (ha/year) & 372 & 180 & 168 & 156 \\
\hline 10. Fuel and oil cost (Tk./year) & $5,01,740$ & $2,53,100$ & $2,71,960$ & $1,83,800$ \\
\hline $\begin{array}{l}\text { 11. Repair and maintenance } \\
\text { cost (Tk./ year) }\end{array}$ & 60,000 & 60,000 & $1,00,000$ & 80,000 \\
\hline $\begin{array}{l}\text { 12. Operators cost }(\text { One } \\
\text { operator }+ \text { two helpers }) \\
\text { (Tk/year) }\end{array}$ & $1,00,000$ & $1,00,000$ & $1,00,000$ & $1,00,000$ \\
\hline 13. Other cost (Tk./year) & 10,000 & 10,000 & 10,000 & 10,000 \\
\hline $\begin{array}{l}\text { b. Variable cost } \\
\qquad(10+11+12+13)(\mathrm{Tk} / \text { year })\end{array}$ & $6,71,740$ & $4,23,100$ & $4.81,960$ & $3,73,800$ \\
\hline c. Total cost $(\mathrm{a}+\mathrm{b})(\mathrm{Tk} / \mathrm{year})$ & $13,83,140$ & $8,50,600$ & $7,33,540$ & $5,76,550$ \\
\hline d. Gross return (Tk/year) & $37,20,000$ & $18,00,000$ & $16,80,000$ & $15,60,000$ \\
\hline e. Net return (d-c) (Tk/year) & $23,36,890$ & $9,49,400$ & $9,46,460$ & $9,83,000$ \\
\hline f. Benefit cost ratio $(d / c)$ & 2.68 & 2.11 & 2.29 & 2.70 \\
\hline g. Payback period (year) & 1.80 & 2.63 & 0.99 & 0.76 \\
\hline
\end{tabular}

Price of diesel $=70 \mathrm{Tk} . / \mathrm{L}$ and lubricating oil $=400 \mathrm{Tk} . / \mathrm{L}$, harvesting charge 10,000 (Tk/ha). 


\section{Farmers' opinions}

Almost $100 \%$ farmers are interested and happy for using combine harvester on custom hiring basis. They expressed the following reasons of their satisfaction and also opined the disadvantages in using combine harvester.

\section{Advantages}

(a) Combine harvesting reduces the human drudgery

(b) It is very quick harvesting method

(c) Harvesting, threshing and winnowing are done at a time and no space is required for threshing and winnowing

(d) It saves the crop from natural calamities as well as shattering loss due to over maturity

(e) It reduces grain loss compared to conventional harvesting, threshing and winnowing methods

(f) It reduces the dependency of scarce farm labour during peak harvesting season. It also reduces turn around time for planting next crop

(g) Harvesting cost is lower than those of manual harvesting, threshing and winnowing of crops.

\section{Disadvantage}

(a) There is no road for transportation of combine harvester through crop field and canal

(b) Price is too high and not affordable to the farmers

(c) Sometimes mechanical disturbances occurred during operation of the machine

(d) It is difficult to harvest inclined $\left(>45^{\circ}\right)$ crops

(e) Rice straw is partially and wheat straw is fully damaged and spread out in the field

(f) For small plot, harvesting by combine harvester is difficult. Corner of the field cannot be harvested properly

(g) If mud in field is more than $15 \mathrm{~cm}$ and sticky harvesters cannot work. Combine harvester is not readily available during the peak harvesting season

(h) Spare parts and skill mechanic are scarce in the rural areas for repair and maintenance of combine harvester

(i) Lack of trained operator for efficient field operation of combine harvester.

\section{Conclusion}

The Metal Private Limited, ACI Motors and Corona Tractors Limited are mainly marketing new and refresh combine harvester in Bangladesh. The Metal Private 
Limited is marketing new CLAAS (India) combine suitable for harvesting both rice and wheat. There are problems of frequent mechanical disturbances and shattering loss of refresh Daedong and Kukje combines. Average time, cost and grain saving by combine harvester over manual methods were $97.5 \%, 35 \%$ and $2.75 \%$, respectively. The benefit cost ratio of CLASS, Daedong, Kukje and Anower combine harvesters were found to be 2.68, 2.11, 2.29 and 2.70, respectively. The payback periods of refresh combine harvesters were lower than the new combine harvester.There were some mechanical problems were observed in refresh combine harvesters during field operations. New harvester was observed almost trouble free and popular to the famers. Scarcity oftrained operator, mechanic service and spare parts are the main problemsin operation, repair and maintenance of the combine harvesters in the field level. Considering the technical performance of combine harvester and demand of the farmers, new combine harvester may be introduced in commercial basis in Bangladesh.

\section{References}

Ahmmed, S. 2014. Present status, prospects and challenges of farm mechanization inBangladesh. In Training Manual 2014: Use of farm machinery and efficientirrigation system management. Jointly published by Bangladesh Agricultural Research Institute, Gazipur and Bangladesh Agricultural Research Council, Farmgate, Dhaka, Bangladesh.

Bala B. K., M. A.Hoque, M. A. Hossain and S. Majumdar. 2010. Post harvest loss and technical efficiency of rice, wheat and maize production system: assessment and measures for strengthening food security. Final Report (CF \# 6/08) submitted to the National Food Policy Capacity Strengthening Programme (NFPCSP), Ministry of Food and Disaster Management, Dhaka, Bangladesh.

Kabir, M. H. and M. M. Zaman.2010. Performance test of CLASS combine harvester in rice field. Journal of Agricultural Engineering 38/AE(1): 71-78.

Pawar, C.S., N.A. Shirsat, and S.V. Pathak, 2008. Performance evaluation of combine harvester and combination of self propelled vertical conveyor reaper with thresher for wheat harvesting. Agriculture Update 3 (1\&2) :123-126.

Prothomalo. 2013. Four in one (Bangla: AakerVitor Char). The daily 'Prothomalo' on 12 June 2013, Dhaka, Bangladesh.

Salassi, M. S. and M. A.Deliberto.2010. Estimating rice combine harvest cost: Performance rate, capital cost, operating cost. Staff Report No. 2010-08. Department of Agricultural Economics and Agribusiness, Louisiana State University Agricultural Center, Baton Rouge, Louisiana. USA.

Talukder, R. K. 2013. Sustainable food system for food security and nutrition: Bangladesh perspective. Keynote paper presented at The World Food Day organized by Ministry of Agriculture, Government of the Peoples Republic of Bangladesh and Food and Agriculture Organization (FAO), Dhaka on 24 October 2013, Dhaka, Basngladesh.

Veerangouda, M. S., Prakash K. V.Sushilendraand M. Anantachar.2010. Performance evaluation of tractor operated combine harvester. Karnataka Journal of Agriculture Sciences 23 (2): 282-285. 